\title{
Arkadiusz Bagłajewski
}

\author{
(Lublin)
}

\section{BLASKI I CIENIE BADAŃ POSTKOLONIALNYCH NAD POLSKĄ LITERATURĄ ROMANTYCZNĄ}

\begin{abstract}
This paper aims at a synthetic presentation of four representative research practices in the first stage of postcolonial studies concerned with Polish literature of the Romantic period. This is currently one of the key tools utilised in the studies of Polish Romanticism, which proved to offer a considerable scope for revisions, especially with regard to the myth of the Borderlands and Messianism, thus enabling major Romantic ideologies and myths to be redefined in terms of identity. An analysis of research discourses reveals the shortcomings and benefits of the postcolonial method when employed in the studies of Polish Romanticism. On the one hand, an all too rigid application of the tools has led to certain interpretive simplifications of Romantic texts, while on the other the authors of the discussed works were able to conceptualize the identities of Polish Romantic literature anew.
\end{abstract}

\section{Key words}

postcolonial studies, Romanticism, analysis of scientific discourse 
Badania postkolonialne nad literaturą polską z ekscytującej nieliczne grono entuzjastów nowinki w ciągu dekady stały się osobną, być może nawet jedną z najbardziej ekspansywnych części - czy subdyscyplin, jak chcą autorzy podręcznika „Teorie literatury XX wieku” Anna Burzyńska i Michał Paweł Markowski ${ }^{1}$ - badań kulturowych w literaturoznawstwie polskim. Pionierska książka Ewy Thompson i jej artykuły ${ }^{2}$, publikowane nie tylko w czasopismach naukowych, szkice Clare Cavanagh i Aleksandra Fiuta z roku 2003, ogłoszone na łamach „Tekstów Drugich”, pierwsze wystąpienia Dariusza Skórczewskiego, zwieńczone w roku 2013 jego fundamentalną książką „Teoria - literatura - dyskurs. Pejzaż postkolonialny”", tłumaczenia podstawowych dla subdyscypliny prac Edwarda Saida ${ }^{5}$, Gayatri Spivak ${ }^{6}$, Leeli Gandhi ${ }^{7}$, Homiego Bhabhy ${ }^{8}$, Anii Loomby ${ }^{9}$ i inne publikacje, zwłaszcza materiały pokonferencyjne ${ }^{10}$, wreszcie - stanowiska krytyczne wobec metodologii postkolonialnej i samych założeń tej postawy emancypacyjno-krytycznej, formułowane nie tylko przez literaturoznawców (jak Grażyna Borkowska ${ }^{11}$ ), ale i przez historyków (Jan Kieniewicz ${ }^{12}$ ) - to wszystko świadczyć może o okrzepnięciu tej dziedziny badań na naszym gruncie ${ }^{13}$. Warto dodać, że

\footnotetext{
${ }^{1}$ A. Burzyńska, M.P. Markowski, Teorie literatury XX wieku. Podręcznik, Kraków 2006, s. 551.

${ }^{2}$ E. Thompson, Trubadurzy imperium. Literatura rosyjska i kolonializm, przeł. A Sierszulska, Kraków 2000.

${ }^{3}$ C. Cavanagh, Postkolonialna Polska. Biała plama na mapie współczesnej teorii, przeł. T. Kunz, Teksty Drugie 2-3, 2003, s. 60-71; A. Fiut, Polonizacja? Kolonizacja?, Teksty Drugie 6, 2003, s. 150-156.

${ }^{4}$ D. Skórczewski, Postkolonialna Polska - projekt (nie)możliwy, Teksty Drugie 1-2, 2006, s. 100-112; D. Skórczewski, Teoria - literatura - dyskurs. Pejzaż postkolonialny, Lublin 2013.

${ }^{5}$ E. Said, Orientalizm, przeł. W. Kalinowski, Warszawa 1991 (II wyd. w przekł. M. Wyrwas-Wiśniewskiej, Poznań 2005 - cytaty z tego wydania); E. Said, Kultura i imperializm, przeł. M. Wyrwas-Wiśniewska, Kraków 2009.

${ }^{6}$ G. Spivak, Strategie postkolonialne, przeł. A. Górny, Warszawa 2011.

${ }^{7}$ L. Gandhi, Teoria postkolonialna. Wprowadzenie krytyczne, przeł. J. Serwański, Poznań 2008.

${ }^{8}$ H. Bhabha, Miejsca kultury, przeł. T. Dobrogoszcz, Kraków 2010.

${ }^{9}$ A. Loomba, Kolonializm/postkolonializm, przeł. N. Bloch, Poznań 2011.

${ }^{10}$ Można tu wskazać niedawno wydane obszerne tomy zbiorowe: M. Buchholtz (red.), Studia postkolonialne w literaturoznawstwie i kulturoznawstwie anglojęzycznym, Toruń 2009; K. Stępnik, D. Trześniowski (red.), Studia postkolonialne nad kulturą i cywilizacją polską, Lublin 2010; B. Bakuła et al. (red.), Dyskurs postkolonialny we współczesnej literaturze i kulturze Europy Środkowo-Wschodniej, Poznań 2015.

${ }^{11}$ G. Borkowska, Perspektywa postkolonialna na gruncie polskim - pytania sceptyka, Teksty Drugie 5, 2010, s. 40-52.

${ }^{12}$ J. Kieniewicz, Ekspansja. Kolonializm. Cywilizacja, Warszawa 2008, s. 207-225, 244-262. Zob. też idem, Polskie pogranicza: próba interpretacji postkolonialnej, [w:] Na pograniczach literatury, J. Fazan, K. Zajas (red.), Kraków 2012, s. 70-72.

${ }^{13}$ Zob. syntetyczne, przeglądowe ujęcia: B. Bakuła, Europa Środkowo-Wschodnia i jej (post)kolonialny świat, s. 13-97 oraz artykuł E. Kledzik, Polska postkolonialna - strategie udomowienia, [w:] Dyskurs postkolonialny we współczesnej literaturze, s. 183-203.
} 
rozwijają się w ostatnich latach badania postzależnościowe, będące propozycją innej niż postkolonializm problematyzacji relacji tożsamościowych, biorące pod uwagę specyfikę szczególnego doświadczenia historycznego, jakie było udziałem naszej części Europy, zwłaszcza w wyniku dominacji komunistycznej po roku 1945 (prace Hanny Gosk ${ }^{14}$ ).

Badania postkolonialne, podobnie jak inne badania kulturowe, określane są jako:

krytyczny namysł nad historią ludzkiej mentalności w tym jej wycinku czy też aspekcie, który wiąże się $\mathrm{z}$ dominacją nad innymi populacjami lub zależnością od nich. Przedmiotem badań prowadzonych $\mathrm{w}$ tym nurcie są bowiem nie tyle „twarde" fakty historyczne, co właśnie s t a n ś w i a d o m o ś c i, którego nośnikiem jest dyskurs wytwarzany w sytuacji spotkania kolonialnego (ang. colonial encounter) przez takie zbiorowości, jak plemię, etnos czy naród ${ }^{15}$.

Badania postkolonialne są więc jednym $\mathrm{z}$ głównych $\mathrm{w}$ dzisiejszej humanistyce ujęć emancypacyjnych, dążących do przepracowania w świetle nowego humanizmu dotychczasowych klisz dyskursywnych wiążących się z opresywną relacją spotkania kolonialnego, kiedy podmiot kolonizujący (imperium) narzucał kolonizowanemu (poprzez podbój, najczęściej zamorski) swój dominujący dyskurs oparty na binarnych opozycjach aksjologicznych (wyższe - niższe, lepsze - gorsze itp.), w wyniku wprowadzenia swej władzy i tym samym swego widzenia Innego. Nie trzeba dodawać, że owo postrzeganie Innego (obcego, nie-białego, „niższego”), było ściśle związane $\mathrm{z}$ narzuceniem przemocy dyskursywnej opartej na kategoriach wytworzonych $\mathrm{w}$ obszarze kultury podmiotu kolonizującego, co tak przekonująco zanalizował Said w swym klasycznym dziele „Orientalizm” i późniejszej pracy „Kultura i imperializm”. Jest więc postkolonializm - jak inne badania kulturowe metodologią opartą na Foucaltowskich kategoriach wiedzy i władzy, poddawanych krytycznej rewizji.

W takim uprofilowaniu badań postkolonialnych, które przedstawiam w wielkim skrócie, dostrzeżono szansę dla rodzimej humanistyki. Musiała się ona wszakże uporać nie tyle $\mathrm{z}$ założeniami teorii, ile $\mathrm{z}$ aplikacją narzędzi w obszarach kultury polskiej różnych epok: wraz z ich specyfiką i różnym, by tak rzec, potencjałem adaptacyjnym, wyrażanym hasłowo w kategorii „skolonizowanego kolonizatora", wprowadzonej od samego początku w obręb polskiej refleksji naukowej ${ }^{16}$. Najkrócej mówiąc: o ile dawna literatura polska

${ }^{14} \mathrm{H}$. Gosk, Opowieści „skolonizowanego/kolonizatora”. W kręgu studiów postzależnościowych nad literaturą polską XX i XXI wieku, Kraków 2010.

${ }^{15}$ D. Skórczewski, Teoria - literatura - dyskurs, s. 12.

${ }^{16}$ Ibidem, s. 79. 
przynosi literackie świadectwa kolonizacji wschodnich obszarów Rzeczypospolitej (pozostawiam na razie na boku kontrowersje związane z tym terminem. Zaznaczam, że rozumiem go jako dyskursywną praktykę reprezentacji hegemona politycznego i kulturowego na ziemiach, które co prawda nie zostały włączone w obręb Rzeczypospolitej w wyniku podboju, lecz na których dominująca kultura polska dokonała swoistego „zawłaszczenia” dyskursywnego, skutecznie polonizując to, co Inne, i zarazem przesuwając Inne poza obszar dominującego dyskursu kulturowego), o tyle literatura XIX i XX w. mierzy się z doświadczeniem opresji kolonialnej będącej wynikiem zaborów i w czasach nam bliższych podległości PRL-u mocarstwu sowieckiemu ${ }^{17}$.

Jak wspominałem, polskie badania postkolonialne należą do najbardziej dynamicznie rozwijających się obszarów w rodzimej humanistyce. Tej ilościowej i jakościowej ekspansji towarzyszą - może nie tak liczne jak w pierwszych latach pączkowania metodologii - powątpiewania w sensowność przeszczepienia formowanej gdzie indziej, w innych okolicznościach historycznych, społeczno-politycznych, metody badania kultury ${ }^{18}$. Biorą się one po części z niezrozumienia istoty operacji adaptacji na naszym gruncie założeń i narzędzi subdyscypliny. O ile pierwsze prace zapoznające polskich humanistów z metodologią postkolonialną podążały za ujęciami demaskującymi opresywność dyskursów kolonialnych (na przykład w utworach dla dzieci i młodzieży), o tyle dość wcześnie sformułowano wyraźnie jako nie tylko postulat, lecz aksjomat konieczność adaptacji założeń i narzędzi metody do szczególnych warunków polskiego doświadczenia postkolonialnego. Było nim doświadczenie „skolonizowanego kolonizatora”, dość dobrze i ekspresyjnie (z nieskrywaną przy tym ironią) wyłożone w wydanej jeszcze w roku 2006 książce Marii Janion „Niesamowita Słowiańszczyzna”. Pisała badaczka:

Spojrzenie od tej strony na naszą współczesną świadomość kulturalną pozwala roz-
szyfrować pewien obecny w niej zawiły wzór. Jesteśmy krajem postkolonialnym,
który jednocześnie - co się nieraz zdarza - odczuwa wyższość wobec swego koloni-
zatora - Rosji. W tym punkcie czuliśmy się i czujemy Europą zmagającą się z azja-
tyckim barbarzyństwem. Jako prawdziwi łacinnicy, katoliccy, śródziemnomorscy

${ }^{17}$ Istnieje propozycja rozdzielenia zakresów badawczych studiów postkolonialnych od postzależnościowych - te drugie dotyczą zasadniczo doświadczenia tożsamościowego wiążącego się z sytuacją zależnościową w PRL-u. Na ten temat prace: H. Gosk (zwł. Opowieści skolonizowanego/kolonizatora) i prace zbiorowe, np. R. Nycz (red.), Kultura po przejściach, osoby z przeszłością, Kraków 2011; H. Gosk, E. Kraskowska (red.), Po zaborach, po wojnie, po PRL: polski dyskurs postzależnościowy wczoraj i dziś, Kraków2013.

${ }^{18}$ Takie stanowisko formułowała G. Borkowska, Perspektywa postkolonialna na gruncie polskim; z tym ujęciem polemizowała E. Thompson, A jednak kolonializm. Uwagi epistemologiczne, Teksty Drugie 6, 2011, s. 298 i nast. 
Europejczycy nie możemy za bardzo utożsamiać się ze Słowiańszczyzną, bo to by nas zbliżało do „gorszości” Rosji. Ale, będąc krajem postkolonialnym, nie jesteśmy przecież prawdziwymi Europejczykami, bo - jako Słowianie - jesteśmy wobec nich wtórni, bo odbiło się na nas rosyjsko-słowiańskie skundlenie. Byliśmy jednocześnie krajem kolonialnym i to kolonizującym pobratymczą Słowiańszczyznę ${ }^{19}$.

Po tych z konieczności skrótowych uwagach pora przejść do syntetycznej prezentacji praktyk badawczych, które z metodologii postkolonialnej uczyniły jedno $\mathrm{z}$ kluczowych dziś narzędzi badań nad literaturą romantyczną. Warto może wskazać, dlaczego romantyzm jest obok literatury powojennej tą epoką, która otwierając najszersze perspektywy badawcze, wzbudza też największe emocje naukowe towarzyszące aplikacji postkolonializmu na polski grunt. Po pierwsze, to w czasach romantyzmu doszło do szczególnego nałożenia na siebie dwóch porządków dyskursywnych: kolonizatora i skolonizowanego z charakterystycznymi interakcjami między tymi matrycami dyskursywnymi. Po drugie - polem owej interakcji stał się wytworzony i stabilizujący się w tej epoce dyskurs o Kresach jako miejscu spotkania kolonialnego tak współcześnie, jak w przeszłości. Tu więc - w czasach romantyzmu - biją źródła mitu kresowego, następnie tak sugestywnie podjętego przez Sienkiewicza i innych twórców; mitu, który ujawniał dwa swoje oblicza: inne w polskim dyskursie tożsamościowym, politycznym, kulturowym, zgoła odmienne w ujęciu ościennych nacji i kultur. Dość przypomnieć dokonane przez Daniela Beauvois nadzwyczaj krytycznego badacza mitu kresów (pisanych przez niego z małej litery, co ma swój wydźwięk emancypacyjny i aksjologiczny) - zestawienie, powstałych, jak twierdzi francuski badacz, pod wpływem "Zamku kaniowskiego”, dwu utworów: „Snu srebrnego Salomei” Słowackiego i „Hajdamaków” Szewczenki ${ }^{20}$. Zaiste, „czar” polskich Kresów rozpływa się, tonąc w obrazach krwi i ognia. Po trzecie wreszcie - potencjał rewizyjny, możliwy do rozbrojenia narzędziami postkolonialnymi tkwi $\mathrm{w}$ najważniejszym bodaj z polskich mitów politycznych XIX w., żywym także, jak się okazuje, i dziś, mianowicie mesjanizmie. Wytłumaczenie dyskursu mesjanistycznego to nie tylko wskazanie naszej odrębności na tle innych zbiorowości europejskich, ale co ważniejsze dla wielu badawczy - ujawnienie potencjału mitotwórczego mesjanizmu jako ideologii niebezpiecznej, anachronicznej historycznie może przyczynić się do uwolnienia myśli polskiej od tej - jak piszą niechętni zjawisku - „aberracji” (tak konsekwentnie określał mesjanizm jego wielki krytyk Czesław Miłosz ${ }^{21}$ ).

\footnotetext{
${ }^{19}$ M. Janion, Niesamowita Słowiańszczyzna. Fantazmaty literatury, Kraków 2006, s. 328.

${ }^{20}$ D. Beauvois, Słowacki iluzjonistyczny, czyli rzeź humańska jako „tragifarsa”, [w:] M. Troszyński (red.), Słowacki współczesny, Warszawa 1999, s. 20-36.

${ }^{21}$ Cz. Miłosz, Szukanie ojczyzny, Kraków 1992, s. 87-89.
} 
Dariusz Skórczewski napisał wręcz, że w humanistycznym projekcie postkolonialnym musi pojawić się romantyzm, przede wszystkim w aspekcie tożsamościowej redefinicji postaw, których źródła biją w czasach Mickiewicza i Słowackiego, a wiążą się z mesjanizmem jako formą kompensacji poczucia niższości. Badacz bardzo wyraźnie podkreśla przy tym, że „problemem” nie jest bynajmniej sam mesjanizm, będący zjawiskiem historycznym, lecz jego współczesna żywotność. Należy więc krytycznie przepatrzeć tę tradycję kultury i jeden z kluczowych „mitów polskich”. Skoro dla badań postkolonialnych kluczowe wydają się problemy związane $\mathrm{z}$ "narracją narodu” (termin H. Bhabhy ${ }^{22}$ ), tym samym mesjanistyczne wyobrażenia, będące podstawą polskiego imaginarium narodowego, powinny być poddane reinterpretacji z wyraźnie zaznaczonym potencjałem dekonstrukcji owego mitu. Ten ogólny projekt został nakreślony w celu redefinicji naszego dyskursu tożsamościowego, zdaniem badacza - w dalszym ciągu pozostającego we władzy paradygmatu romantycznego ${ }^{23}$. Czy nie jest to nazbyt pospiesznie formułowana teza? Panuje tu bowiem dziwne materii „pomięszanie”, mówiąc językiem epoki: winny za nasz współczesny stan skolonizowania umysłowego jest romantyzm (można by się zgodzić, że jako źródło dyskursu tożsamościowego, jego fundament), ale czy nie ponoszą współodpowiedzialności także poromantyczne przeformułowania, Sienkiewiczowskie chociażby? Czy nie należałoby wyraźnie wyostrzonych tez nieco osłabiać, pamiętając, że w kulturze polskiej były także inne wpływowe stanowiska: z lekcją Brzozowskiego i później Gombrowicza na czele? Można oczywiście widzieć w tych projektach swoisty agon kulturowy - pamiętajmy jednak, że zwycięstwo wcale nie musi być ostateczne, a nasze sądy, formułowane w oparciu o dzisiejszy horyzont czasowy, mogą w przyszłości ulec zmianie. Rozumiem oczywiście potrzebę rewizji współczesnego języka mesjanizmu, ale zapytam - jak ma się to dokonać? Czy do współpracy nie trzeba zaprosić innych: pisarzy, filmowców, publicystów? Czy zaproponujemy im temat na zamówienie? To wszystko w kulturze odbywa się inaczej: autentyczne przepracowanie anachronicznych postaw i mitów narodowych powinno wychodzić $z$ wnętrza samej kultury, wsparte rzecz jasna taką, a nie inną pracą samoświadomości twórczej. W swojej polemice wchodzę jednakowoż na inny teren niż zamysł mojego wystąpienia, więc pora wrócić do przerwanych rozważań, pozostawiając $\mathrm{w}$ formie otwartych pytań wyrażone tu wątpliwości.

${ }^{22}$ H. Bhabha, Miejsca kultury, s. 146.

${ }^{23}$ D. Skórczewski, Teoria - literatura - dyskurs, s. 207. 
Chciałbym na przykładach pochodzących $\mathrm{z}$ czterech ujęć z ostatniego dziesięciolecia wskazać - zgodnie z tytułem artykułu - blaski i cienie badań postkolonialnych nad romantyzmem w podwójnej niejako perspektywie: formułowanej przez badaczy wyposażonych $\mathrm{w}$ narzędzia postkolonialne $\mathrm{w}$ ich spotkaniach interpretacyjnych $\mathrm{z}$ utworami romantycznymi oraz przedstawianego na kanwie mojego stanowiska. Oczywiście widzę swoją rolę nie jako arbitra, rozstrzygającego rozmaite kontrowersje, lecz o wiele bardziej skromnie - jako czytelnika stawiającego na kanwie wywodów znawców przedmiotu swoje pytania, niekiedy zastrzeżenia czy wątpliwości, równocześnie podkreślając swoją postawę wyznawcy (mimo oczywistych znaków zapytania) tej metodologii badań literackich.

Jakie stanowiska badawcze chciałbym pokrótce przedstawić? Najpierw pionierskie ujęcie Marii Janion z „Niesamowitej Słowiańszczyzny” (2006) wraz z dopełniającym ujęciem z książki Moniki Rudaś-Grodzkiej „Sfinks słowiański i mumia polska" (2013). Dalej: studia postkolonialne Michała Kuziaka, który niedawno zakończył prace zespołu badającego „Romantyzm środkowoeuropejski w perspektywie postkolonialnej” (dwa obszerne tomy niebawem ukażą się $\mathrm{w}$ druku) oraz swoiste zwieńczenie tego etapu badań (i zapewne wytyczenie kolejnych eksploracji badawczych) w monumentalnej książce Dariusza Skórczewskiego „Teoria - literatura - dyskurs. Pejzaż postkolonialny" (2013). Mam oczywiście świadomość istnienia wielu innych ważnych tekstów, drukowanych przede wszystkim na łamach periodyków naukowych, jak „Teksty Drugie”, „Porównania” czy „Słupskie Prace Filologiczne" ${ }^{24}$, jak również zdaję sobie sprawę, że biblioteka „postkolonialna” w polskim literaturoznawstwie wciąż narasta i zapewne pojawią się kolejne ważne ujęcia. Jednak wybrane przeze mnie prace są reprezentatywne dla pierwszego etapu badań postkolonialnych, związanego z wykreśleniem zjawiska, jego metodologiczną adaptacją, ze stabilizacją terminologiczną i zarysowanymi praktykami badawczymi.

Pierwszą książką będącą świadectwem adaptacji postkolonializmu do badań nad romantyzmem była „Niesamowita Słowiańszczyzna” Marii Janion. To wyrazista lektura rewaloryzacyjna, mająca w zamierzeniu autorki odsłonić alternatywny wizerunek Słowiańszczyzny w polskim piśmiennictwie roman-

${ }^{24} \mathrm{~W}$ numerze monograficznym Słupskich Prac Filologicznych z 2010 r., pod tytułem „Jak czytano i jak czytać romantyzm polski”, znalazły się m.in. prace D. Skórczewskiego (Kilka myśli o romantyzmie i Słowackim z postkolonializmem w tle) i D. Uffelmanna (Litwo! Wschodzie mój!, przeł. M. Kuziak). M. Kuziak i S. Rzepczyński (red.), Jak czytano i jak czytać romantyzm polski, Słupskie Prace Filologiczne, 2010. 
tycznym - wobec innych mitów, zwłaszcza mesjanizmu - tak by w efekcie lektury postkolonialnej można było przeformułować podstawy kultury polskiej, zwłaszcza „odziedziczonej po mesjanizmie megalomanii narodowej”25.

Już w rozważaniach wstępnych Janion zastanawia się, jak można wykorzystać narzędzia postkolonialne do podjętej opowieści o Słowiańszczyźnie ${ }^{26}$. Chodzi badaczce o stworzenie alternatywnej opowieści - i w tym postępowaniu widzi sens współczesnej humanistyki. Zgodnie z postkolonialnym założeniem ma być ona dyskursem emancypacyjnym, zdolnym przy tym do radykalnej dekonstrukcji niebezpiecznych mitów i ideologii (w tym przypad$\mathrm{ku}$ - mesjanizmu). Rozbrojone w wyniku postępowania badawczego szkodliwe mity mają dać asumpt do wyplątania polskiej opowieści z poczucia bezsilności, klęski, naszej peryferyjności. Można nieco ironicznie powiedzieć, parafrazując sens wystąpienia słynnej badaczki: po to, by móc uzdrowić polską duszę, należy ją przeprowadzić przez machinę dyskursywną krytycznej lektury. Pomocna w tym może być nie tylko metodologia postkolonialna (ograniczona tu do Saida i prac pionierów polskiego postkolonializmu, drukowanych w "Tekstach Drugich” i „Europie”), lecz także inne inspiracje badawcze, w tym Freudowska koncepcja „das Unheimliche” (niesamowite), do której swym tytułem - niezbyt czytelnym w polszczyźnie - nawiązuje Janion. „Niesamowita” Słowiańszczyzna - to w istocie „nie-samowita” Słowiańszczyzna, a więc wyrastająca $\mathrm{z}$ „samowitej” (das Heimliche), to znaczy utraconej, zniszczonej, zakrytej dyskursywnie pogańskiej, przedchrześcijańskiej krainy, która zginęła w odmętach dziejów wraz ze swoją bogatą mitologią, kulturą i - last but not least - alternatywną wobec gwałtem ochrzczonej Polski wizją kultury. Pozostały więc ślady, które za romantykami (Dołęga-Chodakowski, Krasiński, Berwiński, Kraszewski) tropi i wydobywa badaczka. Inspiracja postkolonialna $\mathrm{w}$ poszukiwaniu tego, co wymazane, czemu odmówiono głosu i reprezentacji, doczekała się jak zawsze w książkach wybitnej znawczyni romantyzmu udramatyzowanej, atrakcyjnej wykładni narracyjnej, tyleż sugestywnej, ile wzbudzającej u znawców dziejów zasadniczą polemikę ${ }^{27}$. Nie to nas jednak interesuje.

Słowiańska „samowitość" rozpoznawana jest za utworami romantycznymi jako gwałt, swoista amputacja tradycji, co sprawiło, że polska słowiańskość

${ }^{25}$ M. Janion, Niesamowita Słowiańszczyzna, s. 329.

${ }^{26}$ Ibidem, s. 10.

${ }^{27}$ D. Skórczewski, Teoria - literatura - dyskurs, s. 407-425. J. Tazbir, Cienie zapomnianych przodków. O „Niesamowitej Słowiańszczyźnie” Marii Janion: czy Polacy zostali źle ochrzczeni, Tygodnik Powszechny 3, 2007, s. 8-9. 
przedchrześcijańska przenosi w obręb dziejów już chrześcijańskich przeświadczenia o marginalności, nieistotności naszego (oryginalnego) doświadczenia kulturowego. Janion stawia tezę wyrazistą - którą trudno zaakceptować w pełni - oto polski romantyzm wytworzył nowy mit początku ${ }^{28}$, przykryty co prawda traumą doświadczenia chrystianizacji, jednak wyraźnie rezonujący w kulturze epoki. Wyparta, stłumiona, nieświadoma słowiańskość wróciła w serii obrazów u Krasińskiego czy Kraszewskiego. Pytanie zasadne - jak ów powrót ma się do pewnego całościowego obrazu epoki? Na ile ta sugestywna wizja współczesnej badaczki zdolna jest $\mathrm{z}$ marginesu przemieścić się do centrum opowieści naszego romantyzmu? Oczywiście największa obecnie znawczyni epoki ma świadomość miejsca owej słowiańskiej opowieści, zapośredniczonej wszak w romantycznych fantazmatach, i wie, że utopia prasłowiańska nie mogła $\mathrm{w}$ epoce konkurować $\mathrm{z}$ innymi, silnymi mitami zwłaszcza z mesjanizmem. Wie o tym dobrze, ale kreśli takie zdania:

\footnotetext{
W sumie dawna, przedchrześcijańska Słowiańszczyzna stawała się - w dobie utraty niepodległości - ideą romantycznego ocalenia, odmienną od $\mathrm{m}$ e $\mathrm{s}$ a $\mathrm{n}$ i z m u, a zarazem odnajdującą rodzimy pierwiastek zapomnianej oryginalności, związanej przede wszystkim z myślą o pełn o p rawny u d ziale $1 \mathrm{udu}$ w $\dot{\mathrm{z} y c i u}$ obywatelskim (podkr. autorki) ${ }^{29}$.
}

Wszakże rewaloryzacyjny i tym samym humanistyczny sens operacji intelektualnej dokonywanej przez Janion można próbować określić tak: to dla naszego współczesnego samopoznania konieczne jest rozbrojenie miny, jaką jest $\mathrm{w}$ dalszym ciągu mesjanizm, po to, by wydobyć inną - alternatywną opowieść mityczną wobec tego, co szkodliwe, aberracyjne. Należy podstawić w rewaloryzacyjnym geście żywej, współczesnej kultury nową opowieść w postkolonialnym postępowaniu krytycznego przepracowania wątków tożsamościowych (w wymiarze jednostkowym i zbiorowym). Tu jest miejsce dla wątków słowiańskich.

W drugiej części książki autorka, przyglądając się krytycznie mitowi Kresów; opowiada się po stronie Daniela Beauvois ${ }^{30}$, dostrzegającego rozliczne niebezpieczeństwa płynące z kresowych rojeń o wielkości. To mit kompensacyjny, domagający się dekonstrukcji, gdyż usilnie skazuje na naszą przynależność do Zachodu łączącą się z kompleksem "gorszego", bo jednakowoż wschodniego Europejczyka. Można ten mit, jak proponuje Maria Janion,

\footnotetext{
${ }^{28}$ M. Janion, Niesamowita Słowiańszczyzna, s. 27.

${ }^{29}$ Ibidem, s. 97.

${ }^{30}$ Jako autora fundamentalnego dzieła: Trójkąt ukraiński. Szlachta, carat i lud na Wołyniu, Podolu i Kijowszczyźnie 1793-1914, przeł. K. Rutkowski, Lublin 2005.
} 
zastąpić innym - pogranicza; ta alternatywa pozwoli swobodnie zaistnieć cechom „zachodnim”, jak i „wschodnim” (dopowiadając myśl autorki, można tu widzieć tak ważną dla refleksji postkolonialnej „hybrydyczność” jako kategorię poznawczą i opisową zarazem).

Jaki jest związek między przedchrześcijańską Słowiańszczyzną, mitem Kresów a mesjanizmem? Jakkolwiek autorka nie konstruuje struktury wiążącej te różne zjawiska w związek przyczynowo-skutkowy, raczej dostrzega tu relację wzajemnych i nieoczywistych oddziaływań, przepływów, to można próbować inaczej problematyzować owe relacje. Utracona przedchrześcijańska słowiańskość sprawiła, że nie wypracowaliśmy własnego, osobnego modus vivendi, imitując kolonialne miraże i upajając się nimi, popadliśmy po utracie państwa w ambiwalentną reakcję: właśnie skolonizowanego kolonizatora, który swą słabość przykrywa mitami tracącymi związek z rzeczywistością. Miast przeprowadzać debaty polityczne, ugrzęźliśmy w oparach mesjanizmu - i tkwimy w nich do dzisiaj. Oczywiście wyostrzam znacznie subtelniejsze stanowisko autorki, ale bynajmniej nie upraszczam zbytnio stanowiska Janion. Słabość polskiej teodycei narodowej, jak określa się mesjanizm ${ }^{31}$, polega na zapeklowaniu myśli w sferze nie-politycznej, co gorzej, zbudowano zdaniem Janion - na marginesie mesjanizmów romantycznych stereotyp Rosji oparty na binarnych opozycjach: tego, co wschodnie, i tego, co zachodnie. Tkwimy w tych stereotypach do dziś i należałoby je przepracować. Tu trzeba zaproponować lekturę polemiczną: „orientalizacja” Rosji była nie tylko formą samoobrony skolonizowanego podmiotu narodowego, lecz pewną ogólnoeuropejską właściwością wyobraźni politycznej. Pisze Janion: „Polska samoidentyfikacja dokonuje się zazwyczaj poprzez przedstawienie Rosji jako nie w pełni wartościowego, lecz niebezpiecznego Innego" (podkr. autorki) ${ }^{32}$. W polskiej sytuacji, jeśli weźmiemy pod uwagę działania polityczne Rosji na Kresach, stereotypizacja i orientalizacja przeciwnika była zupełnie sensowną strategią samoobrony kulturowej. Ona sprawdziła się - i sporo na ten temat napisano: od pamiętników po prace współczesnych historyków (A. Nowak, J. Kieniewicz, H. Głębocki i inni ${ }^{33}$ ). Można wspomnieć na marginesie, że formułowane na początku XXI w. sądy o konieczności przepraco-

\footnotetext{
${ }^{31}$ M. Janion, Niesamowita Słowiańszczyzna, s. 193.

${ }^{32}$ Ibidem, s. 226-227.

${ }^{33}$ A. Nowak, Od Imperium do Imperium. Spojrzenie na historię Europy Wschodniej, Kraków 2004; idem, Ofiary, imperia i historycy. Studium przypadków (od XVIII do XXI wieku), Kraków 2009, J. Kieniewicz, Ekspansja. Kolonializm. Cywilizacja; H. Głębocki, Kresy imperium. Szkice i materiały do dziejów polityki Rosji wobec jej peryferii (XVIII-XXI wiek), Kraków 2006.
} 
wania naszego myślenia o Rosji z zastosowaniem strategii postkolonialnej są dziś raczej świadectwem życzeniowego myślenia, a nie realnego rozpoznania problemu (zob. rozdział „Ruskie i polskie”).

Mesjanizm - rozpoznawany w epoce tworzących się nacjonalizmów (za Benedictem Andersonem autorka opowiada się po stronie konstruktywistów, znacząco pomijając stanowisko Andrzeja Walickiego, które każe inaczej spojrzeć na romantyczne imaginaria narodowe ${ }^{34}$ ) jako męska tożsamość, ufundowana na wyobrażeniu umarłej Polonii:

Cała polska nowożytna wrażliwość skupia się na melancholijnych obrządkach wokół wyobrażonych kobiecych zwłok, które stają się czczoną relikwią i tworzywem pamiątek ${ }^{35}$.

Nie do końca jasny jest dla mnie związek między alegorią Matki Polonii $\mathrm{z}$ narodowego imaginarium porozbiorowego a mesjanizmem. Czytamy w dalszej części wywodu: „W wyobrażeniach polskich artystów jest to trup, który zmartwychwstanie. Melancholia łączy się istotnie z mesjanizmem" ${ }^{36}$. Nie sposób odmówić badaczce intuicji, kiedy łączy to, co nieoczywiste, ale te radykalne - także językowo - tezy można osłabić, zwracając uwagę na obecny $\mathrm{w}$ alegoriach politycznych, inny od mesjanistycznego przekaz łączony w wyobraźni artystów i poetów z "matczyną" więzią, zadzierzgniętą w czasach przedrozbiorowych między ojczyzną a Polakami. Śmierć ojczyzny to śmierć matki i ów znak równania wydaje się tu ważny - niekoniecznie można go wiązać z mesjanistycznymi znaczeniami. W wyobrażeniach mesjanistycznych - u Mickiewicza czy u Krasińskiego - inaczej niż w alegoriach przedstawiane jest ciało Polski, przygotowywane, by tak rzec, do zmartwychwstania: lotne, eteryczne, odziane w białe szaty odkupienia.

Podsumowując tę cząstkę rozważań, można podkreślić, iż narzędzia postkolonialne użyte zostały w „Niesamowitej Słowiańszczyźnie” do - nawiązując do tytułu innej książki Janion - „odnawiania znaczeń”. Dawne utwory i dawne imaginarium (choć i dziś żywo obecne w zbiorowej świadomości) posłużyły do zarysowania współczesnego projektu kulturowego, który można określić jako antyesencjalistyczny, konstruktywistyczny, wspierający się na krytycznej relekturze trwale oddziaływujących narodowych mitów. Oczywiś-

\footnotetext{
${ }^{34}$ Zob. A. Walicki, Idea narodu w polskiej myśli oświeceniowej, s. 11-12, 53-55. Warto wskazać w tym miejscu, że dyskusyjne jest ujęcie mesjanizmu w pracach Janion i Rudaś-Grodzkiej w perspektywie ahistorycznej, tj. współczesnej oceny tego zjawiska, które bierze w nawias styl myślenia epoki romantyzmu, w to miejsce podstawiając jego współczesną rekontekstualizację. Nie rozszerzam tego wątku, sytuuje się on w innym porządku myślowym niż prezentowany w moim ujęciu.

${ }^{35}$ M. Janion, Niesamowita Słowiańszczyzna, s. 274.

${ }^{36}$ Ibidem, s. 275.
} 
cie, trudno sobie wyobrazić żywotność prasłowiańskich mitów, ale nie o nie w tym projekcie tak naprawdę chodzi. Jakiś zarys alternatywy kulturowej odnajdziemy w zdaniu:

Można by było tutaj wytrzymać i bez słońca Południa, gdyby bardziej różnorodna, wyzwolona z obsesji kolonialnych i postkolonialnych, właśnie kolorowa była nasza kultura $^{37}$.

Do tez z książki Janion nawiązała w swej pracy „Sfinks słowiański i mumia polska” Monika Rudaś-Grodzka prowadząca niezależnie od autorki „Niesamowitej Słowiańszczyzny" badania nad romantycznym imaginarium z wykorzystaniem między innymi narzędzi postkolonialnych (warto dodać, że Janion sięgnęła w swej książce do wielu tez Rudaś-Grodzkiej z jej prac, które dały początek omawianej pracy).

Trudno w tym miejscu przedstawiać szczegółowo bogatą problematykę książki Rudaś-Grodzkiej ${ }^{38}$, dość wskazać, że narzędzia postkolonialne, wespół m.in. z inspiracjami psychoanalizy, gender studies, zaowocowały propozycją ujęcia mitów narodowych romantyzmu w aspekcie postkolonialnej z gruntu strategii nazwania, rewindykacji i zarazem „uzdrawiania” jako swoistej humanistycznej terapii; tak nazwałbym projekt, który w inny sposób (w podobnej co u Janion optyce humanistyki rozbrajającej narodowe mity), w duchu postkolonialnej demaskacji pozwoli wyzwolić kulturę polską ze stanu zależności mitologiczno-mesjanistycznej. Komentując postępowanie badawcze Janion, autorka „Sfinksa słowiańskiego...” dokonała autoprezentacji stanowiska wpisanego w omawianą pracę:

W poszukiwaniu nowej opowieści, która mogłaby pomieścić do tej pory jeszcze
„nieoswojoną" tradycję słowiańską, Janion wskazuje na krytykę postkolonialną,
pozwalającą spojrzeć w innej optyce na obowiązujące wzory polskiej tożsamości
zdominowanej przez mesjanizm i jego produkty: martyrologię i cierpiętnictwo.
Polską mentalność wprost nazywa postkolonialną. Na jej kształt wpłynęły polityka
zaborczego skolonizowania w XIX i XX w. oraz opozycyjne wobec narzuconej wła-
dzy Sienkiewiczowskie marzenie o kolonizowaniu ${ }^{39}$.

Powiedzmy krótko, że autorkę książki interesuje wyjątkowe zapętlenie idei narodowych zogniskowanych wokół utopii słowiańskiej i mesjanizmu, konstruktów wchodzących ze sobą w różnego rodzaju interakcje. Polski nacjonalizm - domagający się przepracowania, po ujawnieniu jego „trucizn” mitologii narodowej - rozpościera się w przestrzeni między słowiańską utopią a me-

${ }^{37}$ Ibidem, s. 330.

${ }^{38}$ Zob. moje obszerne omówienie: A. Bagłajewski, Między Sfinksem a mumią naród wychowany?, Teksty Drugie 6, 2014, s. 205-216.

${ }^{39}$ M. Rudaś-Grodzka, Sfinks słowiański i mumia polska, Warszawa 2013, s. 24. 
sjanizmem. To dlatego dwie części książki przeglądają się jakby w swoim lustrzanym odbiciu: słowiańska utopia, rozpoznawana w pismach ziewończyków, u Kraszewskiego, Zaleskiego, Mickiewicza (w jego prelekcjach paryskich będących także wykładnią mesjanizmu), stająca się „imperialną” kompensacją skolonizowanego podmiotu, śniącego w literaturze mity o odzyskiwanej wielkości mocarstwowej, zestawiana jest $\mathrm{z}$ mesjanistyczną konstrukcją konsolacyjną, będąca przejawem działania - jak podkreśla autorka, wprowadzając inspirowane psychoanalizą kategorię opisu zjawiska - masochizmu moralnego (społecznego) zbiorowości, która klęskę zastępuje fantazjami bólu i cierpienia, dającymi rozkosz kompensacyjnie rozpoznawanej „wielkości”. Tak wygląda, przedstawiany w ogromnym skrócie, ogólny zamysł badawczy Rudaś-Grodzkiej.

W tej niezwykle interesująco pomyślanej całości szczególne miejsce zajmują postkolonialne rewaloryzacje (zawsze uzupełniane innymi inspiracjami metodologicznymi, najczęściej psychoanalizą). Rozsiane są one po całej książce, ale szczególne „zagęszczenie” interpretacja postkolonialna znalazła w dwóch zwłaszcza rozdziałach: „O przyjaźni polsko-ukraińskiej” oraz „Kruche ogniwo. O jedności polsko-ukraińskiej w dumkach Józefa Bohdana Zaleskiego". Przyjrzyjmy się więc nieco bliżej ich zawartości. Dodać warto, że za pracami konstruktywistów autorka książki przygląda się wyobrażonemu narodowi porozbiorowemu (za ujęciem Mochnackiego i Brodzińskiego), który przegląda się w lustrze minionej wielkości, utwierdzając swoją tożsamość poprzez konstrukcję nazywaną „narcystyczną osobowością narodu polskiego", czyli mocną tożsamością utopii słowiańskiej i idei mesjanistycznej.

Zabiegi romantyków, związane z potrzebą stwarzania i zarazem utwierdzania mocnej tożsamości ogniskują się w micie Kresów, będącym z kolei w postkolonialnym spojrzeniu - miejscem z jednej strony "wpisywania” znaczeń kolonizacji, a więc „wymazywania” elementów kultury zastanej (to zresztą moment wymagający dyskusji, na którą $\mathrm{w}$ tym porządku rozważań nie ma miejsca), po to, by z drugiej strony „wpisywać” imperialne znaczenia kultury polskiej (zanalizowane $\mathrm{w}$ rozdziale „Imperium słowiańskie i jego bohater"). Teza Rudaś-Grodzkiej jest wyrazista: w XIX w. polski dyskurs narodowy ignoruje dążenia emancypacyjne innych narodowości. To dlatego we współczesnym postępowaniu rewindykacyjnym należy upomnieć się o pozbawianych głosu Innych (to znaczy pozbawianych $\mathrm{w}$ dyskursie polskim, w dzisiejszym postępowaniu owe głosy ukraińskie wydobywane są, interesująco, chociażby z ukraińskich pieśni ludowych, które polscy romantycy traktowali jako własne; to także jest interpretowane jako przejaw kultu- 
rowej uzurpacji - można powiedzieć na marginesie, że nie stracił racji bytu „tradycyjny” język naukowy, widzący w tym zabiegu przejaw romantycznej „ukrainomanii”, otwarcia na to, co lokalne, co poszerza przestrzeń literatury polskiej w empatycznej relacji dwu kultur, folklorystycznej dawności i jej współczesnej interpretacji). Postkolonialne spojrzenie badaczki jest nacechowane etycznie - rację skłonna jest lokować po stronie „wymazywanych” dyskursywnie mniejszości, stąd pojawiają się jednostronnie wartościowane sądy, w rodzaju: „ «Pęd» Polski do podporządkowywania sobie ziem wschodnich w okresie porozbiorowym”40; „Do najbardziej utartych i długowiecznych, a przez to trujących stereotypów należał pogląd, że Ukraina jest niepodważalnym spadkiem po rycerstwie kresowym" ${ }^{41}$.

Spojrzenie na relacje polsko-ukraińskie konceptualizowane jest za pomocą Freudowskiej kategorii „narcyzmu małych różnic”; w efekcie owa „bliskość” wyzwala relacje antagonistyczne (po jednej i drugiej stronie), co przekreśla szansę dialogicznego układania racji. Skolonizowany kolonizator nie może w tej optyce badawczej - zrozumieć innych racji, widząc w nich pomniejszenie swoich rozpoznań. Zawęźla się takie stanowisko wobec mitu Kresów: dochodzi w nim do „orientalizacji” Ukrainy. Można w tym miejscu zapytać, czy nie jest to stanowisko ahistoryczne w odniesieniu do I połowy XIX w. Nie chodzi bynajmniej o to, że Ukraina wedle powszechnej opinii to "polska kraina”, jak pisał Wincenty Pol w „Mohorcie”. Może nam się dzisiaj takie stanowisko nie podobać, ale nie zmienimy faktu, że był to powszechnie podzielany pogląd, który zupełnie inaczej wybrzmiewał $\mathrm{w}$ pierwszej połowie stulecia, kiedy dążenia Rusinów były jakościowo różne od dążeń z końca XIX stulecia, gdy na fali dążeń emancypacji nacjonalistycznej doszło do zastąpienia nazwy Rusini nazwą Ukraińcy. „Niemy” etnos nie tylko nim był w wyniku "polonizacji” (kolonizacji), lecz taki pozostawał w optyce - jednak - jakiejś atrakcyjności kultury polskiej, hasłowo rzecz ujmując.

Niezależnie od takich lub innych elementów dyskusyjnych w wywodzie badawczym warto podkreślić, że „orientalizacja” ziem ukraińskich, o ile pozostaniemy przy tym terminie, wyraża się w utwierdzaniu przekonań o „niedoskonałości” Ukrainy ${ }^{42}$, co jest rozumiane jako zasadnicza strategia kulturowej kolonizacji. Do wyrazistych przejawów tej strategii należą zdaniem badaczki:

42 Ibidem, s. 189. 
go komplikacje społeczne i narodowościowe. Zaleski na przykład nadaje Kozakom cechy rycerskie, a więc „polskie”, skutecznie osłabiając potencjał narodowościowej autoafirmacji, a w to miejsce podkładając romantyczny koloryt lokalny. Innym przejawem orientalizującym, będzie naznaczenie Zofiówki stemplem „pieczęci magnackiej wytłoczonej na ziemi ukraińskiej" ${ }^{33}$.

W drugiej części książki w optyce „podejrzeń” lokowany jest sprzężony z mitem słowiańskim mesjanizm, rozpoznawany za pomocą psychoanalitycznej kategorii „masochizmu narodowego”, a postkolonialny potencjał rewizyjny, przykładany do tych wielce pomysłowych wywodów, polega na ujawnieniu - by tak rzec - perswazyjnej mocy mesjanistycznej „trucizny”: słowiańskiej dumy, wypracowywanej przez Mickiewicza w prelekcjach paryskich, w jawnej opozycji wobec rozmaicie maskowanej niższości wobec Zachodu. Ambiwalencje prelekcji - ujawniane, o czym piszę dalej, w inny sposób w postkolonialnej lekturze Michała Kuziaka, w sieci sprzeczności, niekonsekwencji - wyraża figura konającego gladiatora jako zapowiedź słowiańskiego losu, który po wiekach cierpień, „niemej” obecności (czyli w istocie nieistnienia $\mathrm{w}$ świadomości Zachodu), po uświadomieniu sobie moralnej przewagi nad Zachodem, zgodnie ze wskazaną przez Herdera wybijającą godziną Słowian, odzyska swój „głos” i wprowadzi słowiański kontynent w obszar Europy. W ten oto sposób zbiorowość, za którą do tej pory historię pisali i piszą inni: hegemoni kulturowi i polityczni, będzie mogła zaistnieć jako podmiot toczącej się historii. Mesjanizm w interpretacji Rudaś-Grodzkiej, jakkolwiek postkolonialnie rozpoznawany i rozumiany, jest jednakowoż ulokowanym w fantazji mitem kompensacyjnym, tym bardziej niebezpiecznym, im mocniej stara się odwrócić od rzeczywistości. To wyraz i przejaw masochistycznej bierności, domagający się przezwyciężenia, gdyż gruntuje nacjonalizm jako kategorię religijną, sakralizując naród - pomniejsza i niszczy tym samym jednostkę oraz Innych. Polski kompleks wymaga zdaniem autorki omawianej książki przezwyciężenia - to także lekcja postkolonialna w lekturze dziewiętnastowiecznych źródeł narodowości.

Podsumowując krótko tę cząstkę wywodów, chciałbym wskazać na istotne „miejsce wspólne” dwu wzajemnie oświetlających się ujęć Janion i Rudaś-Grodzkiej: to wyrastający z postkolonialnego potencjału rewindykacyjno-rewizyjnego postulat przepracowania współczesnej kultury politycznej Polaków, zaczadzonej, zdaniem autorek, oparami mesjanizmu. Postkolonialne czytanie przedsięwzięte zostało po to, by zrozumieć mit mesjanistyczny i go odrzucić. Uświadomienie sobie źródeł megalomanii narodowej, wspie-

\footnotetext{
${ }^{43}$ Ibidem, s. 205.
} 
rającej się na kompleksach niższości, to droga do odmiennego konstruowania narodowej tożsamości: w świadomym odrzuceniu postkolonialnej „skazy”, by budować nową tożsamość, uwolnioną już od kompensacyjnych mitów.

Postkolonialną lekturę utworów Mickiewicza przedstawił w swej książce „Inny Mickiewicz” Michał Kuziak. Przyjrzyjmy się nieco bliżej jego propozycji. Ma ona oczywiście inny charakter niż obszerniej omówione książki Janion i Rudaś-Grodzkiej, ale w dwóch rozdziałach książki Kuziaka (zatytułowanych: „Mickiewicz postkolonialnie (I). Słowiański głos w prelekcjach paryskich” i „Mickiewicz postkolonialnie (II). Wartość kulturowego braku”) dostrzegam duży potencjał inspiracyjny dla dalszych badań postkolonialnych nad romantyzmem.

Kuziak wziął na warsztat prelekcje paryskie Mickiewicza, dostrzegając $\mathrm{w}$ wystąpieniach poety-profesora swoisty projekt kulturowy, będący tyleż ambitnym, ile pozornie „anachronicznym” (ów cudzysłów jest konieczny, bo Mickiewicz jest świadom swoistej „nieprzystawalności” swej myśli do dyskursów dominujących $\mathrm{w}$ europejskim centrum) głosem $\mathrm{z}$ marginesu, $\mathrm{z}$ peryferyjnej Słowiańszczyzny, dla której poeta usiłuje odnaleźć głos $\mathrm{w}$ polifonii dyskursów zachodnioeuropejskich, wikłając z kolei swój głos w wewnętrzne sprzeczności, z których bynajmniej nie wycofuje się w kolejnych kursach. Słowiańszczyzna jest „młodsza”, marginalna, ale dlatego, że taka jest, może przynieść „starej” Europie odrodzenie. Ma odnowić świat polityki, a tym samym dać zniewolonym (skolonizowanym) ludom uczestnictwo w wolności. Warto za Kuziakiem podkreślić potencjał rewaloryzacyjny prelekcji w mesjanistycznie rozumianej profecji, projektującej nowe miejsce Słowian, dotąd pozostających na marginesie dyskursu zachodnioeuropejskiego (obejmującego filozofię, naukę, sztukę), czy też - mówiąc językiem teorii postkolonialnej - skolonizowanych przez centrum. Słowiańskie wystąpienie Mickiewicza, jego reprezentacja Innych jest zasadniczo odmienna od głosów dobiegających na rubieże kontynentu z europejskich stolic: Paryża, Berlina, niebawem Londynu. Polski romantyk eksponuje mesjanistyczne oczekiwanie, a dotychczasową dziejową hibernację - za ujęciem Herdera - rozpoznaje jako moment przybliżający do aktywności mesjanistycznej, czyli duchowego odrodzenia Europy. Takie uprofilowanie stanowiska - w którym ujawnia się postulat emancypacji słowiańskiej - staje jednakowoż w opozycji do głosu centrum, jest radykalnym odwróceniem ukształtowanych już pojęć europejskiego porządku politycznego, a także kulturowego. Czytamy w szkicu „Mickiewicz postkolonialnie (II)": 
Tworzone przez Mickiewicza narracje można odczytać jako opowieść (opowieści) o charakterze kontrhegemonialnym, będącą odpowiedzią marginesu, który wszakże nie chce uznać siebie za margines, (...) skierowaną do centrum ${ }^{44}$.

W postkolonialnej lekturze Kuziaka ważna wydaje się teza o syndromie kolonialnym, jaki ujawnia się w latach trzydziestych XIX w. w refleksji poety: Mickiewicz porzuca wcześniejszy język uniwersalizmu kulturowego, sięgając po język resentymentu, jakim jest mesjanizm. To zarazem - jak wskazuje autor "Innego Mickiewicza”, idąc torem myśli Ewy Thompson - swoiste świadectwo antykolonialnej strategii odzyskiwania własnego głosu, zmiany tożsamościowej, przeformułowania myślenia wspólnotowego. Mickiewicz porzuca optykę ,jagiellońską" (w typologii Thompson: „sarmacką”45), zwracając się ku idei na swój sposób regresywnej. W tym aspekcie postawa polskiego poety jest odmienna od poety zachodnioeuropejskiego - głosi on apologię duchowego ponownego „zaczarowania” świata, „odczarowanego” przez zachodni rozum. Postkolonialne wyzwolenie, będące koniecznością podjęcia i utrzymania misji duchowej, jest zarazem „kolonialnym” wskazaniem wizji nowej Europy, którą oferuje centrom cywilizacyjnym kontynentu budzący się do życia Słowianin; dotąd bierny, uśpiony, pozostający na marginesie cywilizacji i kultury. Ale Mickiewiczowskie odrzucenie nowoczesnej kultury europejskiej ma także inne reperkusje. Inny w geście odrzucenia głosu hegemona ujawnia swoją „wyższość”, przeznaczenie dziejowe oparte na duchowym odnowieniu Europy można widzieć jako przeformułowanie perspektywy orientalizacji $\mathrm{w}$ kierunku innej kolonizacji, dokonywanej przez marginesy zajmujące miejsce dotychczasowego centrum.

$\mathrm{W}$ wystąpieniach poety ujawnia się wszakże ambiwalencja postkolonialna: pragnie wybicia „słowiańskiej godziny”, wielkiego dziejowego przesilenia, ale głosi on idee, od których Europa coraz wyraźniej się odwraca, tak więc można dopowiedzieć - głos poety-profesora grzęźnie w niezrozumiałych dla części publiczności aklamacjach towianistycznych. Mickiewicz w ujęciu interpretatora wystąpił przeciwko dyskursowi orientalizującemu Słowian, lecz w zamian zaproponował mesjanistyczny ton żarliwie natchnionego apostoła zmiany, która miałaby odnowić Europę. Projekt nie tylko, jak się okazało, utopijny, ale też życzeniowy, niebiorący pod uwagę realiów twardej politycznej gry toczącej się w Europie (choć oczywiście diagnoza polityki europejskich mocarstw okazała się trafna).

\footnotetext{
${ }^{44}$ M. Kuziak, Inny Mickiewicz, Gdańsk 2013, s. 135.

${ }^{45}$ E. Thompson, Sarmatyzm i postkolonializm. O naturze polskich resentymentów, Europa. Tygodnik Idei 46, 2006. Cyt. za: M. Kuziak, Inny Mickiewicz, s. 137.
} 
Projekt Mickiewicza, będący projektem emancypacji Słowian (Polaków), również emancypacji dyskursywnej, w istocie pozostaje w obrębie myślenia kolonialnego, jedynie odwracając kierunek działania przemocy, podmieniając jeden Logos innym, zamieniając pozycję centrum i peryferii, proklamując kolejną europejską uniwersalność (tym razem mesjanistyczną), choć twórca podkreśla, że z zachowaniem partykularyzmó $w^{46}$.

To uwikłanie wewnętrzne Mickiewiczowskiego dyskursu można czytać jako świadectwo poszukiwania innego głosu pośród języków politycznych Europy - przenikniętego chrześcijaństwem - jednak finał głoszonej profecji był inny, niż zakładał to na początku swego wystąpienia poeta-prorok, stając się apologetą mesjanistycznej Słowiańszczyzny ${ }^{47}$. Mickiewicz chciał, jak to ujął w liście do Lelewela, „opowiadać ludkom ewangelię narodowości”"48, jednak wypowiadał tę opowieść językiem resentymentu - i ta nieudana próba narzucenia dyskursywnego dobrze odnalazła postkolonialne instrumentarium interpretacyjne.

I wreszcie czwarta próba zastosowania metodologii postkolonialnej do badań nad polskim romantyzmem - fundamentalna, w sensie teoretycznej adaptacji metodologii, praca Dariusza Skórczewskiego „Teoria - literatura - dyskurs. Pejzaż postkolonialny" (2013), o której była już mowa we wcześniejszym wywodzie. Przedstawiłem też w zarysie pewien ogólniejszy projekt "przepatrywania" postkolonialnego romantyzmu, sformułowany przez badacza.

Książka składa się z trzech części: teoretycznej (do której odwoływałem się w wywodzie z pierwszej części artykułu), interpretacyjnej (oprócz takich dzieł romantycznych, jak „Sonety krymskie” czy „Sen srebrny Salomei”, znalazły się postkolonialne interpretacje utworów: Konwickiego, Huellego, Stasiuka, Clark) oraz przynoszącej analizy dyskursów zależnościowych, w tym kresoznawczego. Interesuje nas część interpretacyjna, a ściślej jej cząstka poświęcona postkolonialnej egzegezie dzieł Mickiewicza i Słowackiego, choć oczywiście autorska propozycja interpretacyjna wyrasta $\mathrm{z}$ ujęć teoretycznych - jest próbą zbudowania nowego języka interpretacyjnego, opartego na postkolonialnym instrumentarium, przenoszonym (ostrożnie, na ogół z wyczuciem) ze znakomicie przyswojonej obcojęzycznej literatury teoretycznej. Mówiąc inaczej - dokonywana aplikacja teoretyczna, sprzężona z konsekwencją $\mathrm{w}$ budowaniu pojęciowego instrumentarium postkolonialnego, przełożyła się na osobny dyskurs interpretatora, operującego narzędziami

${ }^{46}$ M. Kuziak, Inny Mickiewicz, s. 131.

${ }^{47}$ Ibidem.

${ }^{48}$ Cyt. za: ibidem, s. 142. 
przenoszonymi z innych ujęć badawczych, adaptowanymi na potrzeby polskich dzieł romantycznych, do nowej problematyzacji owych dzieł literackich - zgodnie z dostrzeżonym w nich potencjałem postkolonialnych problemów. Słusznie zastrzega badacz, że jego interpretacje mają charakter "cząstkowy” $\mathrm{w}$ tym sensie, że obce jest jemu strukturalistyczne marzenie powiedzenia „wszystkiego" o analizowanym utworze. Przeciwnie - dopowiada on te kwestie, które można ująć w problematyzację postkolonialną, poprzez stabilizację pojęciową języka teorii postkolonialnych. Zobaczymy to na przykładach. Warto jeszcze dodać ogólniejszą obserwację - mianowicie nie zawsze ów język interpretatora bywa przekonujący, nie zawsze terminologiczna adaptacja odbrzmiewa w naukowej polszczyźnie, co można rozumieć jako swoiste „mocowanie" się badacza $\mathrm{z}$ oporem materii literackiej zamykanej w ramach metodologicznego, wyrazistego języka. To też zobaczymy na przykładach. Powiedzmy w tym miejscu, że propozycja Skórczewskiego w zakresie adaptacji instrumentarium postkolonialnego wydaje się najciekawsza i najbardziej ambitna spośród omawianych prac, co nie powinno zmieniać obserwacji, że w związku z istnieniem nadzwyczaj bogatej tradycji historycznoliterackiej w odniesieniu do omawianych utworów romantycznych (przez dziesięciolecia narosła ogromna biblioteka prac) jako pilny postulat badawczy rysuje się na horyzoncie odnowienia praktyk interpretacyjnych potrzeba jakiegoś „uzgodnienia” języków interpretacji: dawnej i współcześnie prowadzonej. Nie chodzi bynajmniej o powrót do strukturalistycznej iluzji uchwycenia istoty dzieła, ale raczej o praktykę negocjacji interpretacyjnej, pozwalającą włączyć w obręb odświeżonej czy ukazanej w nowym oświetleniu problematyki ujęcia badawcze dawniejsze (archiwum historycznoliterackie), które odnoszą się do kluczowych aspektów interpretowanych dzieł (a są to często arcydzieła literatury romantycznej).

Warto jeszcze przypomnieć, że swoje interpretacje Skórczewski odnosi do pewnego projektu humanistycznego, inspirowanego rzecz jasna spojrzeniem postkolonialnym na romantyzm. Pisał on bowiem o "gruntownym przemyśleniu twórczości epoki sub specie współczesności"49, nie tyle w celu rewaloryzacji samego romantyzmu, ile zastąpienia i ugruntowania w kulturze współczesnej takiego projektu wspólnotowej tożsamości, który poddając krytyce niektóre mity romantyzmu (jak mesjanizm i zwłaszcza jego dziedzictwo), inne wątki myśli romantycznej, rozpoznawane w optyce postkolonialnej, pozwoli wydobyć i wskazać jako efekty skolonizowania (hybrydyczność toż-

\footnotetext{
${ }^{49}$ D. Skórczewski, Teoria - literatura - dyskurs, s. 186.
} 
samościowa, strategie mimikry) i w akcie samopoznania je przezwyciężyć bądź poszerzyć o nowe inspiracje (np. niepolonocentryczny obraz Innego).

$\mathrm{W}$ rozdziale zatytułowanym „Ekskluzja tubylców w tekście poety imperium? (Adam Mickiewicz, «Sonety krymskie»)” już tytuł rozdziału wprowadza nas w postkolonialne spectrum problemów, terminologii, a także krytycznej rewizji odczytań Mickiewiczowskiego cyklu (także w grę wchodzą inne problematyzacje postkolonialno-tożsamościowe, np. Romana Koropecky'ego). Polemika dotyczy ujęcia Mickiewicza jako „trubadura imperium” (to nawiązanie do głośnej i na polskim gruncie pionierskiej książki Ewy Thompson, poświęconej literaturze rosyjskiej i jej projektowi imperialnemu) i wprowadza nas w sedno problematyki postkolonialnej cyklu. Otóż świat „Sonetów krymskich" to obszar „okcydentalno-orientalnego zderzenia" ${ }^{50}$ realizowanego na różnych planach cyklu: podmiotowym, dyskursywnym, imagologicznym. W lekturze Skórczewskiego odczucie obcości Pielgrzyma poznającego - wespół z Mirzą - Krym, przeistacza się w ambiwalentną dwuznaczność reprezentowania i wymazywania Innego, zgodnie z ogólniejszymi praktykami europejskich dyskursów orientalizujących, jakkolwiek polski romantyk subtelnie, wszakże na marginesach dyskursu dominującego, przywołuje Innego i Inne. Orientalne tło podróży, o którym tak wiele napisano w przeszłości, tu zostaje ukazane jako jedna ze strategii orientalizacji, interpretowana $\mathrm{w}$ fundamentalnym dziele Saida: nadawania znaczeń przez zewnętrznego przybysza, biorącego poznawany i percypowany świat w dyskursywne władanie. Stąd - jak czytamy - Krym jako reprezentacja Wschodu „charakteryzuje się znamienną dla twórczości orientalistycznej amorficznością”51, a poznanie nie dotyczy „krainy dostatków i krasy", lecz jest:

(...)_utajoną formą samopoznania podmiotu, w której faktyczny przedmiot Wschód - ulega substytucji i wyparciu, relegowany do roli pełnej przepychu dekoracji czy też „aneksu do Europy” (podkr. autora) ${ }^{52}$.

Z dotychczasowych rozważań płynie konkluzja, że Mickiewiczowski orientalizm konstruuje Orient jako Innego, przeciwstawionego Zachodowi i w sposób zasadniczy od niego różnego, tak jakby Wschód był terytorium, które istnieje „d l a europejskiego obserwatora" ${ }^{3}$.

Jak widzimy, Saidowskie instrumentarium jest wprowadzone w obszar dyskursywny interpretatora. Inne języki - mówiące o tym samym - zostają

\footnotetext{
${ }^{50}$ Ibidem, s. 224.

${ }^{51}$ Ibidem, s. 228.

${ }^{52}$ Ibidem, s. 229.

${ }^{53}$ Ibidem, s. 233.
} 
odsunięte do archiwum historii literatury. Skórczewski oczywiście dobrze zna literaturę przedmiotu, więc ów gest „archiwizacji” tradycji historycznoliterackiej można potraktować jak jedną z kluczowych strategii postkolonialnego dyskursywizowania obiektu badań. Jeżeli mówi się tu o „lokalnym”, które zostaje poddane dyskursowi władzy „uniwersalnego" (słyszymy tu Foucaultowskie zaplecze myśli postkolonialnej), to tym samym problematyzuje się w innym języku znaną skądinąd tezę o „zachodnich” vs. racjonalnych matrycach poznawczych, w które wyposażony jest Pielgrzym - jako przeciwieństwo Mirzy reprezentującego „wschodni” styl myślenia i odczuwania.

Skórczewski szeroko analizuje Mickiewiczowską strategię "pominięć” Innego, prowadząc $\mathrm{w}$ tym miejscu polemikę $\mathrm{z}$ interpretacjami, które widzą w poecie "trubadura imperium” (taką tezę postawił Roman Koropeckyj, dostrzegając uczestnictwo Mickiewicza w aktualnym porządku władzy); sam zwraca uwagę na ambiwalentną strategię kolonizowania przez skolonizowanego, który przesuwa Innego poza dyskurs, reprezentując go w swojej opowieści. Nie mówi o skolonizowaniu Krymu przez Rosję - zamiast tego określa tę sytuację poprzez aluzje i napomknienia. To nie tylko cenzuralna zasłona, lecz w tej optyce interpretacyjnej odsłonięcie pęknięcia w spójnym - jak twierdzili jednym głosem historycy literatury - zamyśle cyklu. Niemniej - w szczelinach dyskursu nie sposób nie zauważyć podmiotowej „sympatii” dla mieszkańców Krymu, co osłabia „imperialny” gest poety. Mickiewicz jawi się więc w postkolonialnym czytaniu jako poeta pozostający w ambiwalencji, określanej oksymoronem „nieobecnej obecności” jako aporii przenikającej cykl sonetów, natomiast $\mathrm{w}$ odpowiedzi na pytanie, jak rozumieć krymski cykl $\mathrm{w}$ perspektywie postkolonialnej otrzymujemy odpowiedź, wyrażoną $\mathrm{w}$ charakterystycznym dla tej metodologii języku:

(...) proponuję rozpatrywać ten stosunek jako oscylację pomiędzy n i e ch ę c i ą do angażowania uwagi w „ludzki” wymiar aktualnego życia na Krymie a a d m ir a c j ą, jaką budzi w porte-parole Mickiewicza nie tylko bezwzględnie doskonała natura Krymu, lecz również jego zdewastowana i zapomniana kultura ${ }^{54}$.

Jednak najciekawszym romantykiem rozpoznawanym postkolonialnymi narzędziami jest Słowacki - obszernie zaprezentowany jako autor „Snu srebrnego Salomei”, choć Skórczewski w innym miejscu książki przedstawił swoisty projekt czy też zarys możliwej do napisania książki o postkolonialnym Słowackim (syntetyzując także inne ustalenia badawcze).

${ }^{54}$ Ibidem, s. 242. 
„Słowacki pozostaje zawieszony między postkolonialnością a skolonizowaniem" 55 , co znaczy, że w jego twórczości możemy odnaleźć niespotykany gdzie indziej w romantyzmie splot problemów tożsamościowych, postrzeganych w jakościowo odmienny sposób: mówiąc w skrócie, potrafił przesunąć spojrzenie na Innego bliżej jego racji niż racji polskiej strony. Zaproponował też polski poeta "dyskurs negocjacji tożsamości «Wschodu»" ${ }^{56}$ - niejednorodny i wewnętrznie zróżnicowany, mający hybrydyczny charakter (do tej kwestii przyjdzie jeszcze wrócić). W tym dobrze sproblematyzowanym stanowisku badawczym, które zostało następnie przeniesione na praktykę interpretacyjną, obok ogólnie przekonującego stanowiska, są - co zrozumiałe - miejsca wzbudzające gotowość podjęcia polemiki. Nie będę jednak wchodził w spór naukowy, tym bardziej że nie tylko mogłaby na tym ucierpieć przejrzystość wywodu, ale miejscem owej polemiki mogłaby stać się prezentacja własnego stanowiska przedstawianego $\mathrm{w}$ trakcie interpretacji. Czyniąc to zastrzeżenie, chciałbym jednak w tym miejscu wyrazić jedną tylko wątpliwość. Mianowicie słusznie wskazując na przenikającą całą twórczość Słowackiego predylekcję do tworzenia „typów mieszanych”, „miernych” (hybrydyczny status istnienia), Skórczewski określa je przez podobieństwo do "inteligencji comprador" ${ }^{257}$. Nie podoba mi się tak sztywne przenoszenie narzędzi w obszar badań, w którym o inteligencji mówić nie możemy (skoro są tu i postaci historyczne, i przedhistoryczne, „baśniowe”), a bohaterowie bliżsi współczesności mieszczą się w polu dobrze dyskursywnie opisanym jeszcze w literaturze przedromantycznej - zdrady narodowej.

W rozdziale „Hybrydy w polsko-ukraińskim tyglu” (Juliusz Słowacki, „Sen srebrny Salomei”) wyjątkowość dramatu - umieszczanego w perspektywie kulturowego świadectwa kolonizacji Ukrainy - zostaje ukazana wobec kategorii „hybrydy”, szeroko obecnej w dyskursie postkolonialnym, m.in. w ujęciach Homiego Bhabhy ${ }^{58}$. Wydawać by się mogło, że to bardzo ryzykowny pomysł - przenieść nie tylko jedną z kluczowych kategorii badań postkolonialnych, formułowaną w odniesieniu do specyfiki kolonizacji państwa Trzeciego Świata (i tam dobrze się sprawdzającą), w zupełnie odmienny obszar kulturowo-cywilizacyjno-historyczny. Skórczewski ma wszakże świadomość nie tylko konieczności adaptacji narzędzi, ale też potrafił ją zastosować z wycieniowaniem kontekstualnym.

\footnotetext{
${ }^{55}$ Ibidem, s. 210.

${ }^{56}$ Ibidem, s. 214.

${ }^{57}$ Ibidem, s. 213.

${ }^{58}$ H. Bhabha, Miejsca kultury, s. XXXVIII.
} 
Komentując jedno ze stanowisk badawczych, autor omawianej książki wyraźnie sformułował postkolonialną tezę, pisząc, że:

\begin{abstract}
Słowacki w dramacie o koliszczyźnie stworzył taką reprezentację Polski (polskości) i Ukrainy (ukraińskości), która przewartościowywała współczesne poecie idee i koncepcje polityczne oraz rewidowała ocenę historii, przemieszczając centrum dyskursu o problematyce ukraińskiej poza jego dotychczasowe, tradycyjne, polskie jądro. [...] poeta ukazał wypadki 1768 r. jako zdarzenia konstytutywne dla ukraińskiej narracji i narodowego samoprzedstawienia, nadając impetu dążeniom niepodległościowym narodu ukraińskiego ${ }^{59}$.
\end{abstract}

Być może ta nazbyt radykalna teza interpretacyjna domagałaby się osłabienia - nie odmawiającego Słowackiemu zdolności do przedstawienia racji drugiej strony sporu, lecz niekoniecznie podkreślającego ów „impet” dążeń niepodległościowych; zdaje się, że jeszcze jest zbyt wcześnie na taką formułę - lecz nie sposób, podkreślmy, odmówić badaczowi racji, kiedy wskazuje na wpisany w dramat ów empatyczny, rozumiejący styl refleksji wokół pojęć narodowych: ważący racje dwu stron czy też wyraźnie „dowartościowujący” marginalny dotąd głos „ukraiński” (cudzysłów wydaje mi się konieczny, bo to jednak w dalszym ciągu reprezentowanie Innego, choć bliższe jego optyce).

Skórczewski w swej lekturze podważa wyrazistą tezę francuskiego badacza, znawcy problematyki Kresów, historyka Daniela Beauvois, który pisząc o „Śnie srebrnym Salomei”, formułował myśl o pozostawaniu Słowackiego we władzy polskiego ( $v s$. kolonialnego) mitu Kresów, głuchego na racje strony ukraińskiej ${ }^{60}$. Polemizując z Beavois, kreśli Skórczewski ważne w perspektywie postkolonialnej relektury odczytanie, pozwalające dostrzec w dziele Słowackiego „interesujące przełamanie polonocentrycznej monofonii” ${ }^{61}$. Zgadzam się $\mathrm{z}$ tym stanowiskiem, dobrze udowodnionym $\mathrm{w}$ dalszej interpretacji dramatu. Słowacki, rezygnując $z$ arkadyjskiej Ukrainy, typowej dla wcześniejszych przedstawień w kulturze polskiej, dał obraz pełen zapętleń, sprzeczności, których nie wygładza. Włączając w obręb dramatu dwa dyskursy orientalizujące na temat Ukrainy: akadyjski i infernalny, dokonał znamiennych przemieszczeń. Zarazem istotą zabiegu Słowackiego, wydobywanego dzięki optyce postkolonialnej, a który służy przedstawieniu komplikacji tożsamościowych, jest podważenie dotychczasowych ról, rozdzielonych, by tak rzec, w dyskursie tożsamościowym na binarne opozycje, np. „niższości” i „wyższości”, „natury” i „kultury”. Te opozycje umożliwiały orientalizację Ukrainy z jednej strony, z drugiej - stabilizowały stereotypy, unieruchamiając dyskurs. Postkolonialne

\footnotetext{
${ }^{59}$ D. Skórczewski, Teoria - literatura - dyskurs, s. 253.

${ }^{60}$ D. Beauvois, Słowacki idylliczny, s. 27-30.

${ }^{61}$ D. Skórczewski, Teoria - literatura - dyskurs, s. 255.
} 
postępowanie Skórczewskiego, mówiąc w skrócie, pozwala „rozruszać” dyskurs tożsamościowy, ujawniając istnienie w dramacie Słowackiego hybrydalnej tożsamości, wpisywanej niejednoznacznie w postaci. Istotne pojęcie krytyki postkolonialnej odnalazło tu swoją reprezentację dyskursywną wyjątkowo, powiedziałbym, wyraziście. Analizując podmiotowość bohaterów dramatu, badacz dostrzega $\mathrm{w}$ owych hybrydalnych przemieszczeniach powstawanie „silnej podmiotowości ukraińskiej w fazie narodzin”62, utwierdzającej swą tożsamość $\mathrm{w}$ równie silnym akcie sprzeciwu wobec polskiego centrum. Ta dialektyczna gra etnosów nie ma jednak bynajmniej charakteru ścisłego rozgraniczenia narodowościowego, jakkolwiek głos podmiotowości ukraińskiej jest tu wyjątkowo donośnie słyszalny, także na tle innych dzieł romantycznych. Tożsamość narodowa na „pograniczu kulturowym” jest bowiem „negocjowana” (używam terminów proponowanych przez Skórczewskiego), chociaż ów proces negocjacji nie ma charakteru bezkolizyjnej wymiany racji. Przeciwnie - odwołując się tym razem do frenezji Słowackiego - można powiedzieć, że skąpany jest w krwi i ogniu.

„Hybrydyczność” w „Śnie srebrnym Salomei” pozwala z jednej strony ukazać złożoność relacji skolonizowany - kolonizator (vide: Semenko vel Tymenko - ten bohater realizuje strategię mimikry, Salomea, Sawa, Księżniczka, a więc główne postaci dramatu). Z drugiej natomiast - rozbija „monolityczną strukturę dyskursu hegemonicznego"63. Hybrydyczność - za Bhabhą - umożliwia bowiem uzyskanie takiego samopoznania przez podmiot, w którym uzyskuje on krytyczną wiedzę na temat własnego skolonizowania. Zderzenie racji dwu kultur w „spotkaniu kolonialnym” na Kresach powadzi więc do redefinicji dyskursu. Dobrze to widać w chwili uruchomienia przez Semenkę dyskursu „ukraińskiego”, będącego odwróceniem dyskursu "polskiego" (tak jak prezentuje go Regimentarz); w wyniku tej subwersji to Polacy stają się Innymi. Oczywiście finał dramatu nie pozwala na utrzymanie tego stanowiska, ale też nie ma powrotu do stanu wzajemnej wyrazistej separacji. Ukraiński tygiel hybryd zakwestionował uprzednią wyrazistą formułę tożsamości, w której to, co polskie, było elementem bez reszty dominującym („Tożsamość kolonizatora ulega decentryzacji wraz z jego pozycją, tożsamość skolonizowanego zostaje dowartościowana, a jego miejsce w przestrzeni dyskursu przesuwa się z marginesu ku centrum"64).

\footnotetext{
${ }^{62}$ Ibidem, s. 263.

${ }^{63}$ Ibidem, s. 267.

${ }^{64}$ Ibidem, s. 282.
} 
Dlatego też „«Sen srebrny Salomei» staje się symbolicznym dramatem o fiasku polskiej misji cywilizacyjnej wobec Ukrainy"65. Ta konkluzja, będąc rekapitulacją prowadzonego wywodu, jest zarazem postkolonialną reinterpretacją nowatorskiej strategii Słowackiego, który nie tylko oddał głos Innemu, przedstawił jego racje, ale zdaniem badacza potrafił ukazać wewnętrzne komplikacje w obrębie dyskursu kolonizatora i skolonizowanego, nie ważąc racji wyłącznie na zasadzie odwróconej symetrii. Potrafił ukazać przepływy w obrębie dyskursów i przedstawianych racji. Być może wyostrzyłem tu konkluzję Słowackiego w obrębie konkluzji badacza, ale proponowana lektura postkolonialna dobrze uargumentowała taką możliwość interpretacji.

Pora przejść do krótkiego podsumowania. Wnioski cząstkowe pojawiły się $\mathrm{w}$ toku prowadzonego wywodu, nie chciałbym więc ich powtarzać $\mathrm{w}$ tym miejscu. Wystarczy, jeśli wskażę, że reprezentatywne dla pierwszego etapu badań postkolonialnych nad polskim romantyzmem prace przynoszą ważkie ustalenia na wielu różnych polach: zwłaszcza metodologicznym - dokonano bowiem udanej adaptacji metodologii na grunt polskich badań nad epoką romantyzmu, biorąc pod uwagę specyfikę polskiego spotkania kolonialnego, którą było doświadczenie skolonizowanego kolonizatora $\mathrm{z}$ rozmaitymi dla tego typu zjawiska konsekwencjami. Ustabilizowała się także siatka terminologiczna, a konkretne praktyki badawcze zmierzyły się z kluczowym dla polskiego dyskursu kolonialnego zjawiskiem mesjanizmu, rozpatrywanym w kontekście odzyskiwania słowiańskiego głosu, który z marginesu zaczął przesuwać się ku centrum. Tożsamościowy projekt romantyków - w aspekcie lektury postkolonialnej - ukazuje swój głęboko ambiwalentny charakter: jest on bowiem $\mathrm{z}$ jednej strony propozycją ustanowieniu swojego odrębnego głosu, konkurencyjnego wobec zabiegów dyskursywnych hegemona, z drugiej natomiast - stał się źródłem mitów, które utwierdzały i nadal utwierdzają wyrastające $\mathrm{z}$ kompleksów poczucie wyższości. Ta ambiwalencja zdaje się przenikać spojrzenie na doświadczenia skolonizowanego kolonizatora $\mathrm{w}$ kulturze polskiej nie tylko romantyzmu, lecz w ogóle dwóch ostatnich stuleci.

${ }^{65}$ Ibidem, s. 279. 


\section{Arkadiusz Bagłajewski \\ THE BRIGHT AND DARK SIDES OF POSTCOLONIAL STUDIES INTO POLISH LITERATURE OF THE ROMANTIC PERIOD}

\section{Summary}

The author takes a look at a number of major adaptations of postcolonial theory in the studies of Polish literature of the Romantic period. The attention focuses here on the four most important approaches, which in fact conclude the first stage of application of postcolonial theory to Polish cultural achievement. Using the examples of Niesamowita Słowiańszczyzna by Maria Janion (2006), its supplementary project by Monika Rudaś-Grodzka entitled Sfinks słowiański i mumia polska (2013), Michała Kuziak's texts in Inny Mickiewicz (2013) and the fundamental theoretical synthesis which resolves some major issues for the studies of the Romantic period, namely Dariusz Skórczewski's Teoria - literatura - dyskurs. Pejzaż postkolonialny (2013), the author demonstrates a range of practical consequences of implementing postcolonial methodology in the studies Polish literature of the Romanticism. All works harbour a potential for revision, developing a new picture of Romanticism and its legacy, in particular through critical postcolonial analysis of Messianism and discovery of new themes in Polish culture, especially Slavic ones, or those betraying colonial strategies in Polish culture. The interpretation is accompanied by the presumption that Polish postcolonial experience is a unique one, being founded on the relation of a "colonised coloniser". While analysing postcolonial discourses in Polish literature studies, the author points out a number of shortcomings in postcolonial interpretations of Romantic works, which chiefly consist in a mechanical transposition of research tools and an all too rigid application of the methodology.

\section{Bibliografia}

Bagłajewski A., Między Sfinksem a mumią naród wychowany?, Teksty Drugie 6, 2014 , s. 205-216.

Bakuła B. et al. (red.), Dyskurs postkolonialny we współczesnej literaturze i kulturze Europy Środkowo-Wschodniej, Poznań 2015.

Beauvois D., Słowacki iluzjonistyczny, czyli rzeź humańska jako „tragifarsa”, [w:] Słowacki współczesny, M. Troszyński (red.), Warszawa 1999, s. 20-36.

Beauvois D., Trójkąt ukraiński. Szlachta, carat i lud na Wołyniu, Podolu i Kijowszczyźnie 1793-1914, przeł. K. Rutkowski, Lublin 2005.

Bhabha H., Miejsca kultury, przeł. T. Dobrogoszcz, Kraków 2010.

Buchholtz M. (red.), Studia postkolonialne w literaturoznawstwie i kulturoznawstwie anglojęzycznym, Toruń 2009.

Borkowska G., Perspektywa postkolonialna na gruncie polskim - pytania sceptyka, Teksty Drugie 5, 2010, s. 40-52.

Burzyńska A., Markowski M.P., Teorie literatury XX wieku. Podręcznik, Kraków 2006. 
Cavanagh C., Postkolonialna Polska. Biała plama na mapie współczesnej teorii, przeł. T. Kunz, Teksty Drugie 2-3, 2003, s. 60-71.

Fiut. A., Polonizacja? Kolonizacja?, Teksty Drugie 6, 2003, s. 150-156.

Gandhi L., Teoria postkolonialna. Wprowadzenie krytyczne, przeł. J. Serwański, opr. E. Domańska, Poznań 2008.

Głębocki H., Kresy imperium. Szkice i materiały do dziejów polityki Rosji wobec jej peryferii (XVIII-XXI wiek), Kraków 2006.

Gosk H., Opowieści „skolonizowanego/kolonizatora”. W kręgu studiów postzależnościowych nad literaturą polską XX i XXI wieku, Kraków 2010.

Gosk H., Kraskowska E. (red.), Po zaborach, po wojnie, po PRL: polski dyskurs postzależnościowy wczoraj i dziś, Kraków 2013.

Gosk H., Kołodziejczyk D., Historie, społeczeństwa, przestrzenie dialogu. Studia postzależnościowe w perspektywie porównawczej, Kraków 2014.

Janion M., Niesamowita Słowiańszczyzna. Fantazmaty literatury, Kraków 2006.

Kardyni-Pelikanova K., Na marginesie postkolonialnych odczytań w relacjach polskiej i czeskiej literatury, Porównania 6, 2009.

Kieniewicz J., Ekspansja. Kolonializm. Cywilizacja, Warszawa 2008.

Kieniewicz J., Polskie pogranicza: próba interpretacji postkolonialnej, [w:] Na pograniczach literatury, J. Fazan i K. Zajas (red.), Kraków 2012.

Kołodziejczyk D., Postkolonialny transfer na Europę Środkowo-Wschodnią, Teksty Drugie 5, 2010.

Kołodziejczyk D., Wojna światów? Postkolonialny kontrapunkt w nowej komparatystyce, Teksty Drugie 4, 2014.

Kuziak M., Inny Mickiewicz, Gdańsk 2013.

Kuziak M., Nawrocki B., Romantyzm środkowoeuropejski w kontekście postkolonialnym, I, Warszawa 2017

Kuziak M., Maciejewski B., Romantyzm środkowoeuropejski w kontekście postkolonialnym, II, Kraków 2016.

Loomba A., Kolonializm/postkolonializm, przeł. N. Bloch, Poznań 2011.

Miłosz Cz., Szukanie ojczyzny, Kraków 1992.

Nowak A., Od Imperium do Imperium. Spojrzenie na historię Europy Wschodniej, Kraków 2004.

Nowak A., Ofiary, imperia i historycy. Studium przypadków (od XVIII do XXI wieku), Kraków 2009.

Nycz R. (red.), Kultura po przejściach, osoby z przeszłością, Kraków 2011.

Rudaś-Grodzka M., Sfinks słowiański i mumia polska, Warszawa 2013.

Said E., Orientalizm, przeł. M. Wyrwas-Wiśniewska, Poznań 2005.

Said E., Kultura i imperializm, przeł. M. Wyrwas-Wiśniewska, Kraków 2009.

Skórczewski D., Postkolonialna Polska - projekt (nie)możliwy, Teksty Drugie 1-2, 2006, s. 100-112.

Skórczewski D., Teoria - literatura - dyskurs. Pejzaż postkolonialny, Lublin 2013.

Spivak G., Strategie postkolonialne, przeł. A. Górny, Warszawa 2011.

Stępnik K, Trześniowski D. (red.), Studia postkolonialne nad kulturą i cywilizacją polską, Lublin 2010

Tazbir J., Cienie zapomnianych przodków. O „Niesamowitej Słowiańszczyźnie” Marii Janion: czy Polacy zostali źle ochrzczeni, Tygodnik Powszechny 3, 2007, s. 8-9.

Thompson E., Trubadurzy imperium. Literatura rosyjska i kolonializm, przeł. A Sierszulska, Kraków 2000.

Thompson E., Sarmatyzm i postkolonializm. O naturze polskich resentymentów, Europa. Tygodnik Idei 46, 2006, s. 137.

Thompson E., A jednak kolonializm. Uwagi epistemologiczne, Teksty Drugie 6, 2011, s. 298 i nast.

Walicki A., Idea narodu w polskiej myśli oświeceniowej, Warszawa 2000. 
